\title{
IMPROVING STUDENTS' SPEAKING SKILL THROUGH ROLE PLAY: AN ACTION RESEARCH FOR THE EIGHT GRADE STUDENTS OF SMP NEGERI 1 PEDONGGA
}

\author{
Mariani \\ Ruslin \\ Afifah \\ English Department Tarbiyah and Teacher Training Faculty \\ State Institute for Islamic Studies Palu \\ Email:marianijumardi73@gmail.com
}

\begin{abstract}
Speaking is the special moment when the student can be improve their speaking in daily life or their classroom. With speaking the students can practice their knowledge of English and they can get new vocabularies. The objective of the research is to improve speaking skill for the eight grade students of SMP Negeri 1 Pedongga in the academic year of 2019/2020 with the use of role play method. Based on the observation, there were some problems in the teaching and learning of speaking. To solve those problems, the researcher implemented role play as a speaking activity.The research was carried out through action research that consisted of two cycles. Each cycle consisted of two meetings. The results of the research showed that there were some improvements in the students speaking skill. In cycle I, there were some unsuccessful actions. Meanwhile, in cycle II, the implementation of role play techniques was successful in improving the students' speaking skill. The conclusion of this research were the students low in speaking was caused by lack in vocabulary, self-confident, and they were confused how to pronounced the word. The success in teaching doesn't depend on the lesson program only, but more important is how to the teacher present the lesson and uses various method to manage the class.
\end{abstract}

Keywords: Speaking, Role Play, Classroom Action Research 


\section{Background}

As social human, people always interact and communicate one another. The first way to do the interaction and communication is by speaking. That is why speaking is very essential, moreover speaking English. ${ }^{1}$ Indonesian students have to know English in their school as one of the target in learning. There are four skills of English. Speaking is one of the skills and the way how to say something with people around us.

In Indonesia, English is a foreign language. Actually, speaking is the special moment when the student can improve their speaking in daily life or their classroom. With speaking the students can practice their knowledge of English and they can get new vocabularies. Students learning language is considered to be successful if they can communicate effectively in their second or foreign language. This lead to learners' lack of self-confidence and avoidance when communicating with native English speakers. ${ }^{2}$

SMP Negeri 1 Pedongga is one school which is located in West Sulawesi. The school uses curriculum 2013 or Kurtilas. The curriculum applied in seven and eight grade of students SMP Negeri 1 Pedongga. The school has English subject but some of the students there still lack knowledge about English especially in speaking. This is confirmed by the words of one of the English teachers there. Based on the observation, they have low motivation to speak in the class, because they cannot speak English fluently. They still have some problems in mastering speaking

1 Mukminatus Zuhriyah, Storytelling to Improve Students Speaking Skill (English Education: Jurnal Tadris Bahasa Inggris, 2017), 119.

${ }^{2}$ Thanyalak Oradee, Developing Speaking Skills Using Three Communicative Activities (Discussion, Problem-Solving, and Role-Playing), (Thailand: International Journal of Social Science and Humanity, 2012), 533. skills, such as lacks of vocabulary and lacks of opportunity in the real speaking activities to support their pronunciation to speak English, and lack of self-confident. The researcher conducts action research to solve the problems of the students in learning English. The researcher carries out classroom action research since she identifies the crucial problem of speaking especially for the Eight grade students of SMP Negeri 1 Pedongga.

Besides, the other factors causing the low speaking skill are they learn through students' worksheet (LKS) which contains many kinds of task, and list of vocabulary. During the speaking lesson, the teacher asks students to do the exercise in the worksheet (LKS). They just rely on the task in the worksheet. Sometimes they just cheat other students' answer and copy it. If there is a dialogue, the teacher asks them to complete it and read it in front of the class. Considering the importance problem of speaking for the Eight grade student of SMP Negeri 1 Pedongga, the researcher tries to find out the effective solution to improve their speaking by employing role play as an activity in teaching speaking. Role play is believed to be effective to improve speaking skill because it provides different contexts which make it possible for them to act different roles at difference situation.

\section{Literature Review}

Speaking is the way how to express something to someone or people around us. Nowadays, most college students are passive in oral English learning. They are tired of the traditional methods of teaching English and not interest in reading or just reciting the English texts. Therefore why the students have the low motivation of learning oral English and how to solve this problem become the key points of 
improving the researcher's English speaking teaching. ${ }^{3}$

Conversation is one of the most frequent and fundamental means of communication, and its primary and overriding function is the maintenance and establishment of social relationships. ${ }^{4}$ No wonder that when learning a second language, one of the most frequent aims is being able to speak the language, and the acquisition of other skills such as reading or writing is often seen to be secondary to speaking. Thus understanding how one produces speech in an L2 is highly important in order to aid the teaching of this skill. By being familiar with the mental processes involved in producing L2 speech, teachers can understand the problems their learners have to face when learning to speak, course book writers can produce more efficient teaching materials, and language testers can develop instruments that can measure oral language competence in a more valid way. ${ }^{5}$

According to Ladousse in Allan Maley role play is one of a whole gamut of communication techniques which develops fluency in language, which promotes interaction in the classroom, and which increases motivation. Not only in peer learning encouraged by it, but also the sharing between teacher and students' responsibility for the learning process. ${ }^{6}$

Much current discussion of roleplay has occurred within the context of a

${ }^{3}$ Xu Liu, Arousing the College Students' Motivation in Speaking English through Role-Play ( Beijing: International Education Studies, 2010), 136

${ }^{4}$ Nurdin, N. (2009). Segregasi Dalam Pengajaran Dan Penguasaan Bahasa. MUSAWA, l(1), 23-41.

5 Judit Kormos, Speech Production and Second Language Acquisition (London: Lawrence Erlbaum Associate, 2006), xvii.

6 Gillian Porter Ladousse, Role play: Resource Books for Teachers (New York: Oxford University Press,1987), 7. protracted debate over the use of deception in experimental social psychology. Inevitably therefore, the following account of role-playing as a research tool involves some detailed comment on the 'deception' versus 'honesty' controversy. Role-play is defined as participation in simulated social situations that are intended to throw light upon the role/rule contexts governing 'real life' social episodes. ${ }^{7}$

Role play is a popular pedagogical activity in communicative language teaching classes. Within contains set forth by the guidelines, frees students to be somewhat creative in their linguistic output. In some version, role play allows some rehearsal time to students can map out what they are going to say. And it has the effect of lowering anxieties as students can, even for a few moments, take on the persona of someone other than themselves. As an assessment device, role play opens some windows of opportunity for test takers to use discourse that might otherwise be difficult to elicit. With prompts such as "pretend that you're a tourist asking me for direction" or "you're buying a necklace from me in a flea market, and you want to get a lower price," certain personal, strategic, and linguistic factors come into the foreground of the test-taker oral abilities. While role play can be controlled or "guided" by the interviewer, the technique take test-taker beyond simple intensive and responsive levels to a level of creativity and complexity that approaches real-world pragmatics. Scoring presents the usual issues in any task that elicits somewhat unpredictable response from the test-takers. The test administrator must determine the assessment objectives the role play, then devise a scoring technique

7 Louis Cohen, Lawrence Manion, and Keith Morrison, Research Method in Education (New York: Routledge, 2007), 448. 
that appropriately pinpoints the objectives. 8

Based on the definition above, role play is a speaking activity where students as a participant or somebody else in specific topic or situation. It means that role play is the way how to express or imitate someone else. It he role play, students must be focus in speaking English. Role play is a method that can be improve students' ability in target language, it makes students to speak and have interaction with their friends or others, increase motivation and makes the teaching learning process more enjoyable. Role play in the classroom is a form of instruction in which you have students take the part of someone else so that they can understand a situation from a different perspective than they normally would. However, it is not a perfect form of instruction, as it has both advantages and disadvantages to its use.

The advantages of role play, based on Ladousse ${ }^{9}$ as follows:

a. A very wide variety of experience can be brought into the classroom through role-play. The range of functions and structures, and the areas of vocabulary that can be introduces, go far beyond the limits of other pair or group activities, such as conversation, communication games, or humanistic exercises. Through role play we can train our students in speaking skills in any situation.

b. Role play puts students in situations in which they are required to use and develop those phatic forms of language which are so necessary in oiling the works of social relationships, but which

8 H. Douglas Brown, Language Assessment: Principal and Classroom Practice (San Fransisco:2003), 172.

${ }^{9}$ Gillian Porter Ladousse, Role play: Resource Books for Teachers (New York: Oxford University Press, 1987), 6-7. are so often neglected by our language teaching syllabuses. Many students believe that language is only to do with the transfer of specific information from one person to another. They have very little small talk, and in consequence often appear unnecessarily brusque and abrupt. It is possible to build up these social skills from a very low level through role play.

c. Some people are learning English to prepare for specific roles in their lives: people who are going work or travel in an international context. It is helpful for these students to have tried out and experimented with the language they will required in the friendly and safe environment of a classroom. For these students, role play is a very useful dress rehearsal for real life. It enables them not just to acquire set phrases, but to learn how interaction might take place in a variety of situations.

d. Role play helps many shy students by providing them with mask. Some more reticent members of a group may have a great deal of difficulty participating in conversations about themselves, and in other activities based on their direct experience. These students are liberated by role play as they no longer feel that their own personality is implicated.

e. Perhaps the most important reason for using role play is that is fun. Once students understand what is expected of them, they thoroughly enjoy letting their imagination rip. Although there does not appear to be any scientific evidence that enjoyment automatically leads to be agree that in the case of the vast majority of normal people this is surely so.

The disadvantages of Role Play as follows:

a. Embarrassment and discomfort. Role play situations might not flesh out quite 
like you hope because some students are embarrassed and thus tentative about acting out a part in a dramatic. This will cause a role play situation to be awkward and unproductive because one or more students will not be able to participate. When a student feels selfconscious, he will be more likely to be worried about what others will think of him, rather than how the situation can be solved. Children may also a problem with the activity if they cannot fathom how their character might think or behave.

b. Disorganization and inattention. In larger class, role play cannot be done effectively because not all of the students have the option to participate. Many role play scenarios use only two or three individuals in a situation, so the rest of the students just have to watch. This will cause them to become disinterested and stop playing attention. If you try to make the situation incorporate more students, the role play might become a chaotic mess with everyone talking at the same time. Children sometimes act silly when they feel uncomfortable, which can trigger other inappropriate behaviors such as teasing and snickering. Role plays work best when the teacher first explains the purpose and outlines ground rules so children don't mistake the lesson for an acting exercise and get carried away. ${ }^{10}$

\section{Methodology}

This research entitled "Improving Students' English Speaking Skill Through Role Play at the Eight grade students of SMP Negeri 1 Pedongga in 2019/2020 academic year. The aim of the research was

${ }^{10}$ Jonathon Swift.

https://classroom.synonym.com/advantagesdisadvantages-role-play-classroom-7959726.html. June 25, 2018. to improve the students' speaking skill through role play. The researcher tried to improve the way of teaching speaking especially by using role play activity to the students. The subject of the research were the Eight grade students of SMP Negeri 1 Pedongga. The class had 28 students, consisting of 13 female, and 15 male students. The design of this research used a classroom action research. This research was conducted in some cycles to solve the problems discovered in the teaching and learning process based on the observation and interview. In accordance with McTaggart cited in Burns action research has four stages: planning, action, observing, and reflecting.

The scheme of action looks like this:

Figure 1 The Action Research Cycles

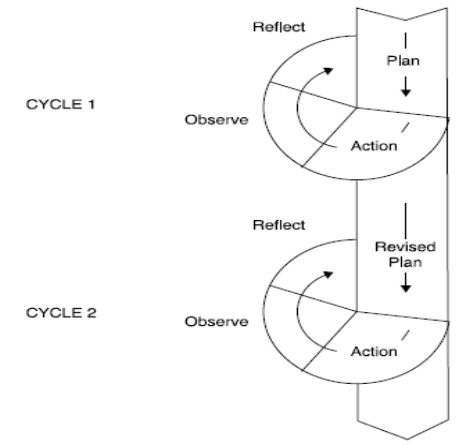

Adopted by Kemmis and Mc Taggart 1998 in Burns 2010: 9

In collecting the data, the researcher used two instruments. They are observation guidelines and interview guideline.

\section{Observation}

Observation guidelines were used in the reconnaissance and action and observation steps. In reconnaissance step, the observation was used to find out the existing problems. Meanwhile, in the action and observation steps, the observation was used to see the implementation of the actions.

\section{Interview}

Interview were used in reconnaissance steps. In reconnaissance step, the interview guidelines were used to find the existing 
problems in the field. Interview was used to know the effectiveness of the actions. In this research, the researcher interviewed the English teacher and the students about comprehensive information related to the teaching and learning speaking process.

\section{Documentation}

The documentation provides data in the form of photographs. The photographs were collected by using a camera as the instrument. They support the main data of this study.

\section{Findings}

The research findings present the description of reconnaissance and the implementation of the action in the teaching learning process. There were two cycles in teaching learning process, each cycle divided two meetings.

\subsection{Reconnaissance}

In this step, the researcher identified problems which occurred in the English teaching learning process at the eight grade students of SMP Negeri 1 Pedongga. The researcher identified problems related to the teaching of speaking. The field problems were collected through a classroom observation, an interview with the English teacher, some interviews with the students. To begin with, the researcher conducted a classroom observation on Tuesday, May $14^{\text {th }}, 2019$.

After doing the observation, interviewing the English teacher and some students, the researcher did conclusions about the problems occurred in the class. Based on the conclusions, the researcher identified some problems that were found in the field. First, the students lack of confidence to express their expression in English. Second, They were difficulties of making pronunciation and vocabulary mistakes when they were speaking. Lack in vocabulary make the students did not speak, the students had difficulties in spell English, and most of students were shy to speak English. Besides, the teacher taught the students by using students' worksheet (LKS) and followed by all of learning activities from it. Therefore, most of them shy of showing their speaking ability in front of the class.

After the field problems were identified, the researcher were focused on the teaching technique and the students. The problems were taken because it affected the students' speaking skill. Therefore, the problems needed to be solved soon. It was expected that solving the problems carried out improvements to their speaking skill.

The following table shows problem and action related to solved related to the fields problem.

Table 1: Action to solved the problem

\begin{tabular}{|l|l|l|}
\hline No & Problem & Action \\
\hline 1. & $\begin{array}{l}\text { Students were } \\
\text { shy and } \\
\text { passiver to } \\
\text { speak English } \\
\text { because their } \\
\text { lack in } \\
\text { confident. in }\end{array}$ & $\begin{array}{l}\text { lolenting } \\
\text { activity wiay } \\
\text { different topic } \\
\text { and different } \\
\text { given situation } \\
\text { in rach } \\
\text { language used. }\end{array}$ \\
\hline $\mathbf{2 .}$ & $\begin{array}{l}\text { The students } \\
\text { had } \\
\text { difficulties in in } \\
\text { pronunciation } \\
\text { and } \\
\text { vocabulary } \\
\text { mistake. }\end{array}$ & $\begin{array}{l}\text { The researcher } \\
\text { gaver some } \\
\text { kinds test of } \\
\text { pronunciation } \\
\text { and } \\
\text { vocabulary in } \\
\text { teaching } \\
\text { speaking }\end{array}$ \\
\hline
\end{tabular}

\subsection{The implementation of action}

After knowing the situation of the students, the researcher implemented the action by teaching speaking skill through 
role play. The classroom action research covered two cycles. Each cycle consisted four steps which includes: 1 . Planning the action, 2. Implementation the action, 3. Observing the action 4. Reflecting the observation result. Every cycle was held in two meetings, and every meeting spent about 45-60 minutes. Topics discussed in the first and second cycle were introduced yourself and what are you doing. It was undertaken from May $14^{\text {th }}$ until July $10^{\text {th }}$ 2019.

The more detail description of the implementation can be seen in the following section.

\section{a. Cycle 1}

\section{1). Planning the action}

The action plan for the first cycle was made based on the problem identified. The researcher conducted an action by using role play to improve student's speaking skill. Before the action was implemented, the researcher prepared the lesson plan and everything related to action research.

\section{2). Implementation the action}

In the first cycle, the researcher explained about introduce yourself, make an example and asked them to make a dialog based on the topic. The first cycle was conducted in two meetings. The action was divided in three terms, namely opening, main activity, and closing.

\section{a. The first meeting \\ 1. Opening}

On Monday, $20^{\text {th }} 2019$, the lesson start at $09.00 \mathrm{am}$. I started by greeting the students, I said "Assalamu'alaikum, good morning students!" the students answered, "Waalaikumussalaam, good morning, too mem". The chairman prepared the class there are say greeting and pray before study. Then, I checked their attendance list. After that, I make a short conversation with them like asking about their habits in the classroom.
Before I told them about what topic that we have to learn today, I introduce myself first. In this meeting, they were surprised to me. After that, I explained to them and make a short example conversation about the topic.

\subsection{Main activity}

Firstly, I asked them about what is introduce yourself in bahasa. I said,"What is the meaning of introduce yourself in bahasa?" they answered, "artinya memperkenalkan diri,kak". I asked one of students, Amanda about how to introducing yourself. Then, I asked Nassaruddin with the same question. Finally, I asked them one by one. Some of them have a good pronunciation, but some of the also confused what should they said to introduce their self.

\section{Closing}

Before I closed the class, I told them to find out how to introduce yourself in front of your friends and we were going to learn it next meeting. I said to them, "Next meeting kakak mau bagi kelompok, dek" they answered, " Iya kak". The chairman prepared the class to pray before they were go home.

\section{b. The second meeting}

\section{Opening}

On Tuesday, May $21^{\text {st }} 2019$, I start the lesson at $08.45 \mathrm{am}$ and I opened the lesson after all the students came to the class. The chairman directly prepared the class like giving greetings and pray before they were studied. After that, I checked attendance list and make a short conversation with them.

\section{Main activity}

Firstly, I asked them about what lesson that we have been learn yesterday. I said, " Ada yang masih ingat materi kemarin?" they answered, "Masih kak, tentang perkenalan diri". I said, "Oke, 
thank you dek. Contohnya bagaimana e?" then, Dwi said "Seperti my name is Dwi, I live in Merambeau". "Good student, thank you so much, Dwi”.

I divided into 2 groups. Each group must made a conversation about introduce yourself. Ade Asti asked me, "Apa semua yang mau diperkenalkan kak?" "Perkenalkan namamu, alamatmu, umur, pokoknya kalau bisa lengkap, kasi lengkap dek". The class was very noisy. The students practice their conversation with their friends loudly. Some of them still confused what should they asked for their friends. During they were made a conversation, I told them to pay attention first. I told them that I assess their pronunciation and accuracy. "attention please, saya akan nilai accuracy dengan pronunciation nya kamu dek. Jadi pronunciation itu adalah pengucapan kata dan accuracy ini adalah ketepatan dek. Nah, ketepatan yang di maksud adalah kemampuannya kamu dalam menggunakan tanda baca, misalnya. Contohnya, kalo dapat tanda baca titik (.) berarti harus berhenti, kalo dapat tanda question mark atau tanda tanya (?) berarti harus?" Dwi said, "Harus bertanya kak". "Nah, thank you Dwi". They were surprised. Alya asked me, "kalo salah ucap bagaimana kak?" "Tidak kenapa, nanti di ajarkan dek". I answered. Then, they were present their group in front of the class.

\section{Closing}

I closed the class before the bell rang. I asked them about what subject that we have been learn today. Dwi said, "Introduce yourself, kak" I said, "ok, thank you Dwi. What else?" The situation were silent. "Ada lagi?" Nassar said, "Itu kak tentang pengucapannya dalam bahasa Inggris juga" "Ok, thank you so much, Nassar". After that, the chairman prepared the class for greeting and say thanks to the teacher.

\section{1) Observing the action}

Observing was very important to do, because it was done to know the students improvement. The researcher observed the whole speaking activities by each group. There were the students did their task careless and not did their task. They started talking or asking their friends, but the students still lack in vocabulary and low ability in speaking test.

Besides, the students still had problems in speaking. The problem were:

1. Pronunciation

The students had the difficulties in pronouncing word correctly, for example in pronounce the word "color", "can", "street", "father", "mother", and etc.

\section{2) Reflection the action result}

From the observation above, it showed that the result of cycle 1 needed to improvement. There were any problem that needed to be solved in the next cycle. Some of the students had difficulties in making conversation with their friends because they don't know how to pronounced the word. Besides there were some students who did not make a conversation with their friends because they were lack in confident and vocabulary.

\section{5). Field Notes}

Researcher $\quad$ : Mariani
Skill $\quad$ : Speaking
Day $\quad$ Tuesday, May $21^{\text {st }} 2019$
Time Observation : 08.45
Method : Role-Play
a. Pre-teaching

1) The researcher came to the class at 08.30 .

2) The researcher greeted the students by saying " assalamualaikum "

3) The researcher checked the attendance of students.

4) The researcher gave some explanation about the material that would be studied. 
5) The researcher used two languages, English and Indonesian in explaining the lesson, but Indonesian was used more than English when the researcher was teaching.

b. While-teaching

1) The researcher asked the students to make a conversation about the topic.

2) Several representative of the students in pairs were asked to practice the conversation.

3) After that, the researcher asked the students to make a group.

4) After that, the students in groups practiced the conversation.

5) The researcher took the score of the students one by one from their performance.

c. Post-Teaching

1) The researcher tried to review the subject and asked the students to study again the subject given that day at home.

2) The teacher closed the class by saying "wassalamualaikum and see you next meeting"

Based on the problem that identified in the first cycle, tried to makes a discussion with an expert and the English teacher about what step that the researcher do in the next cycle. The result of the discussion were the researcher have to change the management class and try a new topic for them. An expert asked me, "So, if your students have a problem like that, what should you do?" I answered, "I will give them motivation to study more and make the class enjoyable and I teach them how to pronounced the word". Finally, our discussion were finished.

\section{b. Cycle 2}

\section{1). Planning the action}

The action plan for the second cycle was held based on the problem occurred in the first cycle. The problem were (1) the students still lack in vocabulary (2) the students still confused how to pronounce the word, they made a lot of mistake in pronunciation (3) the students lack in confident.

Before doing the cycle 2, I should create different task. I changed 2 groups become 5 groups. The technique was chosen to solved the problem from the noisy class. The technique made the student more focus with their group.

\section{2). Implementing the action}

The action was implemented by the researcher. The topic presented in the cycle 2 was what are you doing. The implementation of the action in the cycle 2 consisted of two meeting. Each meetings was divided into three terms, namely opening, main activity, and closing.

\section{a. The first meeting \\ 1. Opening}

On Monday, June $17^{\text {th }} 2019$, I started the class at 09.00 , as usual I greeted the students. The chairman prepared the class before they were going to study, I checked attendance list. I told them the subject about what are you doing.

\section{Main activity}

Firstly, I explained with them about the meaning of what are doing. I said," What are you doing adalah apa yang kamu lakukan. So, what are you doing dipakai untuk menannyakan sebuah aktivitas atau kegiatan yang di lakukan oleh seseorang. Have you ever hear about what are doing? Sudah pernah dengar kalimat what are doing, dek?" they answered, "Sudah kak." "Yang bagaimana itu dek? Can you give me an example?" I asked them. Alya said, "Bisa begini kalimatnya kak, what are you doing yesterday?" "Yes, good student. Thank you Alya. Ada contoh lain?” I asked them. "What are you doing, what are you doing apa e? bingung saya mau tanya apa kak" Iffa answered, and everybody laugh. 
Secondly, I gave them example in daily life. I said, "Kalau bahasa sekarang bilang, bikin apa kau?. Kalau di Palu kakak biasa bilang sama temannya kakak, b apa kau? Kalau orang di Inggris bilang what are you doing. Any questions? Ada pertanyaan,dek?". They said, "Tidak ada kak". After that, I divided them into the group. There were 5 groups. Each group consist of 4-5 students. I asked them, "Kamu pilih sendiri teman kelompoknya atau kakak yang pilihkan?" Nassar answered, "Kakak saja yang pilih, karena disini biasa baku geng kakak, nanti itu terus saja temannya". Then, I gave them a short conversation in a paper and they were read it in front of the class with their group. Before they were practical, I told them the pronounce and accuracy in speaking.

\section{Closing}

Before I closed the lesson, I told them about their homework. Their homework were to find out a short conversation about everything, like family, friendship, school, etc. I told them to practice the conversation in front of the class. As usual, the chairman lead the class before the bell rang.

\section{b. The second meeting \\ 1. Opening}

On Tuesday, June $18^{\text {th }} 2019$, I start the class as usual. I greeted the students, pray before study, and checked attendance list. I told them that the subject same with last meeting.

\section{Main activity}

Firstly, I asked them about the material in last meeting. "Who's still remember the subject yesterday? Ada yang masih ingat materi kemarin?" I asked them. "Masih kak, tentang doing. What are you doing kalo tidak salah". Dwi answered. "Yang bertanya tentang kegiatan yang dilakukan oleh seorang teman kakak toh?" Ade Asti asked me. "Yes, betul dek". After that, I asked them about their homework that I gave yesterday. I do appreciated their homework, although some of them still lack in confident. Secondly, before they were going to practice their conversation in front of the class. I told them that I assess their pronunciation and accuracy. Nassar said, "Saya takut salah ucap kak" "It's okay, dek. Jangan takut salah. Kakak belum pernah makan orang". Everybody laugh. Amanda said, "Kakak saya malu sebenarnya ini, diketawakan temantemanku nanti”, I answered, "Tidak usah malu dek, kakak juga dulu sama seperti begini. Tapi kalo di coba terus lama-lama hilang malu sudah". I told them that the other group still wait their turn out of the class while the other group practice their conversation in the classroom. The students agree with me. This is the way how to manage the class not noisy than before. Then, I chosen the group who already to practice in the classroom. During they were practice, I record them used my handphone. After they were finished their practice, I told them to came in the classroom. I correctly their pronunciation and accuracy group by group.

\section{Closing}

Before the bell rang, I reviewed again about the lesson. They were pay attention carefully about what we were learning and asked them to collect their task. I told them that this is last meeting I teach them and I also told them to always study in home. Then, the chairman lead to pray before went home.

\section{3). Observing the action}

The researcher observed the activity of the students from cycle 2 . In the first meeting, the researcher presented an example of conversation and shared it with them. Some of them not actively in the classroom, only the confident students that made the class alive. 


\section{4). Reflecting the action}

Based on the observation research, the researcher reflected the reflection of the cycle 2 as follows: (1) the students can be participate in the situation they wish (2) the students who lack in confident can take part in role play.

The researcher use role play in teaching speaking to improve students' speaking skill and classroom situation become alive. Role play developed the students active in the classroom, even though the situation was noisy.

\section{5). Field Notes}

Researcher : Mariani

Skill : : Speaking

Day : Tuesday, June $18^{\text {th }} 2019$

Time Observation : 08.45

Method

: Role-Play

a. Pre-teaching

1) The researcher came to the class at 08.30 .

2) The researcher greeted the students by saying "assalamualaikum and good morning student "

3) The students pray before study then the researcher checked the attendance of students.

4) The researcher gave some explanation about the material that would be studied.

5) As usual the researcher used two languages, English and Indonesian in explaining the lesson, but Indonesian was used more than English when the researcher was teaching.

b. While-teaching

1) The researcher asked the students to make a conversation about the topic.

2) Several representative of the students in pairs were asked to practice the conversation.

3) After that, the researcher asked the students to make a group.
4) After that, the students in groups practiced the conversation.

5) The researcher took the score of the students one by one from their performance.

c. Post-Teaching

1) The researcher tried to review the subject and asked the students to study again the subject given that day at home.

2) The teacher closed the class by saying "wassalamualaikum and see you next time students"

\section{Discussion}

The sub-chapter presents the general finding of the actions applied in Cycle 1 and Cycle 2 in the research. In connection with the aim of the research that was improving speaking skill of the eight grade students at SMP Negeri 1 Pedongga through role play, the actions applied were done to attain the goal.

Table 2: The score of cycle 1

\begin{tabular}{|l|l|l|l|l|}
\hline No & Name & Pron. & Acc. & Score \\
\hline 1 & Dwi & 80 & 75 & 77 \\
\hline 2 & Iffa & 75 & 70 & 72 \\
\hline 3 & Usran & 60 & 55 & 57 \\
\hline 4 & Andika & 60 & 55 & 57 \\
\hline 5 & Bagus & 60 & 55 & 57 \\
\hline 6 & Resti & 75 & 70 & 72 \\
\hline 7 & Ifah & 80 & 75 & 77 \\
\hline 8 & Marina & 80 & 75 & 77 \\
\hline 9 & Citra & 75 & 70 & 72 \\
\hline 10 & Amanda & 80 & 75 & 77 \\
\hline 11 & Alya & 80 & 75 & 77 \\
\hline 12 & Ade Asti & 80 & 75 & 77 \\
\hline 13 & Aril & 75 & 60 & 67 \\
\hline 14 & Adi & 70 & 60 & 65 \\
\hline 15 & Nurul & 70 & 65 & 65 \\
\hline 16 & Salena & 75 & 65 & 70 \\
\hline 17 & Firman & 75 & 70 & 72 \\
\hline 18 & Yeka & 70 & 60 & 65 \\
\hline 19 & Yusuf & 70 & 60 & 65 \\
\hline 20 & Nassar & 80 & 75 & 77 \\
\hline 21 & Arya & 75 & 70 & 72 \\
\hline
\end{tabular}




\begin{tabular}{|l|l|l|l|l|}
\hline 22 & Yodi & 75 & 70 & 72 \\
\hline 23 & Sandi & 73 & 65 & 69 \\
\hline 24 & Niko & 75 & 65 & 70 \\
\hline 25 & Maria & 80 & 70 & 75 \\
\hline 26 & Tantri & 79 & 70 & 74 \\
\hline 27 & Tasya & 75 & 70 & 72 \\
\hline
\end{tabular}

$$
\begin{aligned}
\text { Average } & =\frac{\text { Total student's score }}{\text { Students'number }} \\
& =\frac{1.901}{27} \\
& =70
\end{aligned}
$$

Table 3: The score of cycle 2

\begin{tabular}{|l|l|l|l|l|}
\hline No & Name & Pron. & Acc. & Score \\
\hline 1 & Dwi & 88 & 77 & 82 \\
\hline 2 & Iffa & 79 & 71 & 75 \\
\hline 3 & Usran & 70 & 60 & 65 \\
\hline 4 & Andika & 65 & 60 & 62 \\
\hline 5 & Bagus & 70 & 60 & 65 \\
\hline 6 & Resti & 78 & 75 & 76 \\
\hline 7 & Ifah & 80 & 80 & 80 \\
\hline 8 & Marina & 80 & 80 & 80 \\
\hline 9 & Citra & 78 & 75 & 76 \\
\hline 10 & Amanda & 80 & 80 & 80 \\
\hline 11 & Alya & 80 & 77 & 78 \\
\hline 12 & Ade Asti & 80 & 76 & 78 \\
\hline 13 & Aril & 78 & 70 & 74 \\
\hline 14 & Adi & 75 & 70 & 72 \\
\hline 15 & Nurul & 75 & 70 & 72 \\
\hline 16 & Salena & 78 & 75 & 76 \\
\hline 17 & Firman & 75 & 72 & 73 \\
\hline 18 & Yeka & 78 & 65 & 71 \\
\hline 19 & Yusuf & 77 & 65 & 71 \\
\hline 20 & Nassar & 85 & 76 & 80 \\
\hline 21 & Arya & 78 & 72 & 75 \\
\hline 22 & Yodi & 78 & 72 & 75 \\
\hline 23 & Sandi & 77 & 69 & 73 \\
\hline 24 & Niko & 77 & 69 & 73 \\
\hline 25 & Maria & 80 & 75 & 77 \\
\hline 26 & Tantri & 85 & 75 & 77 \\
\hline 27 & Tasya & 85 & 75 & 77 \\
\hline & & & & \\
\hline
\end{tabular}

$$
\begin{aligned}
\text { Average } & =\frac{\text { Total student's score }}{\text { Students'number }} \\
& =\frac{2.013}{27} \\
& =75
\end{aligned}
$$

After analyzing the data in the classroom with score of cycle 1 and cycle 2 of the students, the researcher findings some the improvement of speaking skill through role play.

1. The first findings is role play give students chance to speak with their own way. As stated by Harmer that one of communication activities in English language teaching (ELT) is role-play, because it can be used to encourage general oral fluency or to train the students for specific situations ${ }^{11}$. It developed their speaking skill even though they were lack in confident. The implementation of group work in the classroom helps them to communicate each other or share their knowledge with his/her friends in limited time.

2. The second findings is the students shows a good response. It can be seen from their participation. The improvement could be seen in their behavior. The students were ready in the class when the teacher entered and they were ask question when found difficulties about the subject.

3. The third findings is the improvement the students speaking skill was shown in the result of cycle 1 and cycle 2 . Meanwhile, the problem still exist. The problem were pronunciation, low in vocabulary, and lack in confident. Besides, the students also were active consulting to dictionary when they had

11. Jeremy Harmer. How to teach English: An Introduction to the Practice of English Language Teaching (Assex: Longman, 2001), 325. 
difficulties to finding words or by asking their friends.

\section{Conclusion}

The conclusion of this research is to improve the speaking skill of the eight grade students of SMP Negeri 1 Pedongga in academic year of 2019/2020 by implementing the role play. After carrying out all the process of this research, there are some conclusions that can be drawn. They are presented as follows:

1. The low speaking skill of the eight grade students of SMP Negeri 1 Pedongga was caused by the lack of vocabularies, lack in confident, and they were confused how to pronounced the word. Teacher rarely gave them the opportunity to practice the speaking activity.

2. The implementation of role play could improve the students' speaking skill. It was fun activities that the students got new activities in the classroom.

3. The use of role play in the classroom, it makes the class alive because the students as a participate and they can become anyone or in any situation they wish.

\section{Suggestion}

The success in teaching doesn't depend on the lesson program only, but more important is how the teacher present the lesson and uses various technique to manage the class more lively and enjoyable. After concluding the result of research, the researcher would like to propose some suggestion to the following:

1. English teacher

The teacher can divide the students into group to make them more communicative and active in joining the class. The important is the teacher not as teaching them, but also their facilitating in the class. The English teacher should present the language in an enjoyable, relaxed, and understandable way.

2. The students

The implementation of role play as a speaking activity are useful and important to improve the students' speaking skill. The students should be more active in a group. The students should take part much in acting out role play.

3. The other researcher

Since the researcher conducted the research in junior high school, the other researcher may conduct this research in other levels such as senior high school which have different characteristic than junior high school. 


\section{References}

Burns, A.1999. Collaborative Action Research for English Language Teacher. Cambridge: Cambridge University Press.

Burns, A.2010, Doing Action Research in English Language Teaching: A guide for Practitioners. New York. Routledge.

Byrne, D. 1986. Teaching Oral English: Longman Handbooks for English Teacher. Singapore: Longman Group.

Brown , H. Douglas.2001,Teaching by Principles: An Interactive Approach to Language Pedagogy. San Francisco: Longman.

Brown, H. D.2003,Language Assesment: Principal and Classroom Practices. San Fransisco: Blackwell.

Cohen, L. Manion, L. and Morrison, K.2007,Research Method in Education. New York: Routledge.

Doff, A. 1988. Teach English: A Training Course for Teachers trainer.s Handbooks. Cambridge: Cambridge University Press Inc. The British Council.

Gower, R. Phillips, D. Walters, S. 1995. Teaching Practice Handbook.Great Britain: The Bath press.

Harmer, J. 2001.How to Teach English: An Introduction to the Practice of English Language Teaching. Essex: Longman. 2007. The Practice of English Language. Third Edition. Essex: Longman. 2008. The Practice of English Language Teaching. Harlow:Longman/Pearson Education.

Jonathon Swift.

https://classroom.synonym.com/adv antages-disadvantages-role-play- classroom-7959726.html. June 25, 2018.

Kormos, J.2006,Speech Production and Second Language Acquisition. London: Lawrence Erlbaum Associate.

Ladousse, Gillian P. 1987. Role Play: Resources Books for the Teacher. New York: Oxford University Press.

Liu, X.2010,Arousing the College Students' Motivation in Speaking English Through Role Play. Beijing: International Education Studies.

Nurdin, N. (2009). Segregasi Dalam Pengajaran Dan Penguasaan Bahasa. MUSAWA, 1(1), 23-41.

Soleh, M. Et al.2014.Pembelajaran speaking dengan metode Role Play menggunakan teks berbentuk narrative pada siswakelas XI SMA Negeri 1 Kotabumi Lampung Utara in academic year 2013/2014.

Oradee, T.2012,Developing Speaking Skills Using Three Communicative Activities,Discussion, ProblemSolving, Role-Playing. Thailand: International Journal of Social and Humanity.

Ur, Penny. 1997. A Course in Language Teaching. Cambridge: Cambridge University Press

Zuhriyah, M.2017,Storytelling to Improve Students Speaking Skill. Jombang: English Education: Jurnal Tadris Bahasa Inggris. 